\title{
Genotoxic Effects of Exposure to Formaldehyde in Two Different Occupational Settings
}

\author{
Susana Viegas ${ }^{1,2}$, Carina Ladeira1,2, Mário Gomes'1, \\ Carla Nunes ${ }^{2}$, Miguel Brito ${ }^{1}$ and João Prista ${ }^{2}$ \\ ${ }^{1}$ Escola Superior de Tecnologia da Saúde de Lisboa, Instituto Politécnico de Lisboa, \\ ${ }^{2}$ Centro de Investigação e Estudos em Saúde Pública, Escola Nacional de Saúde Pública, \\ Universidade Nova de Lisboa, \\ Portugal
}

\section{Introduction}

Formaldehyde $\left(\mathrm{CH}_{2} \mathrm{O}\right)$, the most simple and reactive aldehyde, is a colorless, reactive and readily polymerizing gas at room temperature (National Toxicology Program [NTP], 2005). It has a pungent suffocating odor that is recognized by most human subjects at concentrations below 1 ppm (International Agency for Research on Cancer [IARC], 2006).

Aleksandr Butlerov synthesized the chemical in 1859, but it was August Wilhelm von Hofmann who identified it as the product formed from passing methanol and air over a heated platinum spiral in 1867. This method is still the basis for the industrial production of formaldehyde today, in which methanol is oxidized using a metal catalyst. By the early $20^{\text {th }}$ century, with the explosion of knowledge in chemistry and physics, coupled with demands for more innovative synthetic products, the scene was set for the birth of a new materialplastics (Zhang et al., 2009).

According to the Report on Carcinogens, formaldehyde ranks 25th in the overall U.S. chemical production, with more than 5 million tons produced each year (NTP, 2005). Formaldehyde annual production rises up to 21 million tons worldwide and it has increased in China with 7.5 million tons produced in 2007. Given its economic importance and widespread use, many people are exposed to formaldehyde environmentally and/or occupationally (Nazaroff et al., 2006).

Commercially, formaldehyde is manufactured as an aqueous solution called formalin, usually containing $37 \%$ by weight of dissolved formaldehyde.

This chemical is present in all regions of the atmosphere arising from the oxidation of biogenic and anthropogenic hydrocarbons (International Programme on Chemical Safety [IPCS] 1991; Granby et al., 1997). Formaldehyde concentration levels range typically from 2 to $45 \mathrm{ppbV}$ (parts per billion in a given volume) in urban settings that are mainly governed by primary emissions and secondary formation (Chen et al., 2002; Naya \& Nakanishi, 2005). 
Primary formaldehyde is emitted from motor vehicles and fugitive industrial emissions, while secondary formaldehyde is produced by the photochemical oxidation of volatile organic compounds (VOCs) as the result of intense sunlight, especially during summer months (Odabasi \& Seyfioglu, 2005). In addition, it has been postulated that formaldehyde can be produced by reactions involving anthropogenic and naturally occurring alkenes (Chen et al., 2002).

Removal of formaldehyde from the atmosphere can occur by chemical transformations, rain and snow scavenging of vapours and particles, by dry deposition of particles, and by vapour exchange across the air-water interface. Particle/gas phase distribution of formaldehyde is an important factor in determining its atmospheric fate, transport, and transformation (Odabasi \& Seyfioglu, 2005).

Considering indoor air presence, homes containing large amounts of pressed wood products such as hard plywood wall paneling, particleboard, fiberboard, and UreaFormaldehyde Foam Insulation (UFFI) often have elevated levels of formaldehyde emissions exceeding 0.3 ppm (U. S. Environmental Protection Agency [USEPA], 2007). Since 1985, the Department of Housing and Urban Development has only allowed the use of plywood particleboard that conforms to the $0.4 \mathrm{ppm}$ formaldehyde emission limit in the construction of prefabricated and mobile homes (USEPA, 2007). Formaldehyde emission levels generally decrease as products age. In older homes without UFFI, concentrations of formaldehyde emissions are generally far below $0.1 \mathrm{ppm}$ (USEPA, 2007). This value is close to the indoor limit, $0.1 \mathrm{mg} / \mathrm{m}^{3}(0.08 \mathrm{ppm})$, recommended by the World Health Organization (World Health Organization - Regional Office of Europe [WHO-ROE], 2006), the limit followed by many other countries including the UK (Committee on the Medical Effects of Air Pollutants [COMEAP], 2004), and China (Standardization Administration of China [SAC], 2002).

Moreover, some studies have reported that seasonal variations resulted in higher indoor formaldehyde concentrations during the summer due to increased off gassing promoted by the higher temperatures (Kinney et al., 2002; Ohura et al., 2006; Yao \& Wang., 2005). It seems that besides the type of materials used and home age also the season (warmer temperatures) influence formaldehyde concentrations in indoor settings (Viegas \& Prista, 2010; Zhang et al., 2009).

Small amounts of formaldehyde are naturally produced in most organisms, including humans, as a metabolic byproduct (IARC, 2006; NTP, 2005), and are physiologically present in all body fluids, cells and tissues. The endogenous concentration in the blood of humans, monkeys and rats is approximately $2-3 \mathrm{mg} / \mathrm{L}(0.1 \mathrm{mM})$ (Casanova et al., 1988; Heck et al., 1985). Formaldehyde is also found in foods, either naturally or as a result of contamination (IARC, 2006). Therefore, everyone is continually exposed to small amounts of formaldehyde, environmentally present in the air, our homes and endogenously in our own bodies (Zhang et al., 2009).

Taking into account occupational settings, exposure involves not only workers in direct production of formaldehyde and products containing it, but also in industries utilizing these products, such as those related with construction and household (Zhang et al., 2009). The most extensive use of formaldehyde is in production of resins with urea, phenol and melamine, and also polyacetal resins. These products are used as adhesives in manufacture 
of particle-board, plywood, furniture and other wood products (IARC, 2006). Formaldehyde is also used in cosmetics composition and has an important application as a disinfectant and preservative, reason why relevant workplace exposure may also occur in pathology and anatomy laboratories and in mortuaries (Goyer et al., 2004; IARC, 2006; Zhang et al., 2009).

The exposed workers, commonly found in resin production, textiles or other industrial settings, inhale formaldehyde as a gas or absorb the liquid through their skin. Other exposed workers include health-care professionals, medical-lab specialists, morticians and embalmers, all of whom routinely handle bodies or biological specimens preserved with formaldehyde (IARC, 2006; Vincent \& Jandel, 2006; Zhang et al., 2009).

Concerning exposure limits in occupational settings, Occupational Safety and Health Administration (OSHA) has established the following standards that have remained the same since 1992: the permissible exposure limit (PEL) is $0.75 \mathrm{ppm}$ (parts per million) in air as an 8 -h time-weighted average $\left(\mathrm{TWA}_{8 \mathrm{~h}}\right)$ and the short-term $(15 \mathrm{~min})$ exposure limit (STEL) is $2 \mathrm{ppm}$. American Conference of Governmental Industrial Hygienists (ACGIH) recommended threshold limit value (TLV) is $0.3 \mathrm{ppm}$ as a ceiling value. The National Institute of Occupational Safety and Health (NIOSH) recommends much lower exposure limits of $0.016 \mathrm{ppm}\left(\mathrm{TWA}_{8 \mathrm{~h}}\right)$ and $0.1 \mathrm{ppm}$ (STEL), above which individuals are advised to use respirators if working under such conditions. In Portugal, the Portuguese Norm (NP 1796 - 2007) points also $0.3 \mathrm{ppm}$ as a ceiling value.

The primary metabolite of formaldehyde is formate which is not as reactive as formaldehyde itself and can either enter into the one-carbon metabolic pool for incorporation into other cellular components, be excreted as a salt in the urine, or further metabolized to carbon dioxide (Agency for Toxic Substances and Disease Registry [ATSDR], 1999). The metabolic pathway to formate production is catalyzed by cytosolic glutathione (GSH)- dependent formaldehyde dehydrogenase (FDH). The reaction of formaldehyde with GSH yields (S)hydroxymethylglutathione which, in the presence of NAD+ and FDH, forms the thiol ester of formic acid via the action of (S)-formyl glutathione hydrolase (SFGH) (Pyatt et al., 2008).

There is scientific evidence conclusively demonstrating that inhaled formaldehyde does not enter the systemic circulation to modify normally present endogenous levels (ATSDR, 1999; Heck \& Casanova, 2004). This is likely due to the high water solubility of formaldehyde and its rapid metabolism. The lack of systemic distribution is evidenced by a variety of studies in rodents, monkeys and humans (Pyatt et al., 2008).

It seems clear that as long as inhaled levels of formaldehyde are below concentrations that can be rapidly metabolized by tissue formaldehyde dehydrogenase and other highly efficient detoxification enzymes, normal endogenous concentrations $(0.1 \mathrm{mM})$ of formaldehyde in the blood do not increase (ATSDR, 1999; Heck \& Casanova, 2004).

Human studies have shown that chronic exposure to formaldehyde by inhalation is associated with eye, nose and throat irritation (Arts et al., 2008). Sensory irritation leads to reflex responses such as sneezing, lacrimation, rhinorrhea, coughing, vasodilatation and changes in the rate and depth of respiration. The latter results are a decrease in the total amount of inhaled material resulting in a protective effect to the individual. Trigeminus stimulation is not necessarily an indication of cell or tissue damage. At higher concentrations formaldehyde will lead to cytotoxic reactions; this cytotoxic respiratory tract 
irritation is a localized pathophysiological response to a chemical, involving local redness, swelling, or itching (Arts et al., 2006).

Formaldehyde was long considered as a probable human carcinogen (Group 2A chemical) based on experimental animal studies and limited evidence of human carcinogenicity. More recently, several studies report a carcinogenic effect in humans after chronic exposure to formaldehyde, in particular an increased risk for nasopharyngeal cancer (Armstrong et al., 2000; Coggon et al., 2003; Hildesheim et al., 2001; Lubin et al., 2004; Vaughan et al., 2000). Since 2006, IARC classifies formaldehyde as carcinogenic to humans (Group 1), based on sufficient evidence in humans and in experimental animals (IARC, 2006). IARC also concluded that there is a "strong but not sufficient evidence for a causal association between leukemia and occupational exposure to formaldehyde".

The "strong" evidence for a causal relationship between formaldehyde exposure and leukaemia comes from recent updates of two of the three major industrial cohort studies of formaldehyde-exposed workers (Hauptmann et al., 2003; Pinkerton et al., 2004). These data have strengthened a potential causal association between leukemia and occupational exposure to formaldehyde, especially for myeloid leukemia (Zhang et al., 2009).

Nevertheless, some authors have argued that it is biologically implausible for formaldehyde to cause leukaemia (Cole \& Axten, 2004; Marsh \& Youk, 2004). Their primary arguments against the human leukemogenicity of formaldehyde are: (1) it is unlikely to reach the bone marrow and cause toxicity due to its highly reactive nature; (2) there is no evidence that it can damage the stem and progenitor cells, the target cells for leukemogenesis; and (3) there is no credible experimental animal model for formaldehyde-induced leukaemia. This led Pyatt et al., (2008) to recently comment that "the notion that formaldehyde can cause any lymphohematopoietic malignancy is not supported with either epidemiologic data or current understanding of differing etiologies and risk factors for the various hematopoietic and lymphoproliferative malignancies". Indeed, IARC itself concluded that "based on the data available at this time, it was not possible to identify a mechanism for the induction of myeloid leukaemia in humans" and stated that "this is an area needing more research" (IARC, 2006; Cogliano et al., 2005; Zhang et al., 2009).

However, recently, IARC reaffirmed the classification of formaldehyde in Group I, based on sufficient evidence in humans of nasopharyngeal cancer. Considering the possible association with leukemia the epidemiological evidence has become stronger and IARC has concluded that there is sufficient evidence for leukaemia, particularly myeloid leukaemia (Baan et al., 2009; Hauptmann et al., 2009; IARC, 2006).

Moreover, in 2010 Schwilk and colleagues performed an up-dated meta-analyses focusing in higher exposure groups and myeloid leukemia and included two large recent studies and conclude that formaldehyde exposure is associated with increased risks of leukemia, particularly myeloide leukemia and highlight the importance of focusing on high-exposure groups and myeloid leukemia when evaluating the human carcinogenicity of formaldehyde (Schwilk et al., 2010).

In the case of formaldehyde exposure assessment and considering that health effects seems to be mainly related with the high concentration peaks than with long time exposure at low levels, the strategy to perform exposure assessment in occupational settings must be based on the determination of ceilings concentrations. This option might be the best to evaluate 
exposures and to obtain data for risk assessment development (Hauptmann et al., 2009; IARC, 2006).

Manifold in vitro studies clearly indicated that formaldehyde can induce genotoxic effects in proliferating cultured mammalian cells (IARC, 2006). Furthermore, some in vivo studies detected changes in epithelial cells (oral and nasal) and in peripheral lymphocytes related to formaldehyde exposure (Speit \& Schmid, 2006; Suruda et al., 1993).

Frequency of micronucleus (MN) in buccal and/or nasal mucosa cells is being used to investigate local genotoxicity. According to reports concerning experimental genotoxicity studies, MN are the most sensitive genetic endpoints for detection of formaldehyde induced genotoxicity (Merck \& Speit, 1998). Thus, MN test with exfoliated cells could be a powerful tool for detection of local genotoxic effects in humans, which is fundamental for hazard identification and risk estimation (Speit \& Schmid, 2006).

MN in peripheral blood lymphocytes has been extensively used to evaluate the presence and extend of chromosome damage in human populations exposed to genotoxic agents. As advantages, this $\mathrm{MN}$ test provides a reliable measure of chromosomal breakage and loss at lower cost and more easily than chromosomal aberrations. Moreover, the availability of cytokinesis-block technique eliminates potential background caused by effects on cell division kinetics (Bonassi et al., 2001).

Research work has been developed to know occupational exposure to formaldehyde in two different occupational settings (resins production and in pathology and anatomy laboratories) from Portugal and, also, study eventual health effects related with exposure. The objective of this chapter is to describe the work developed and discuss the obtained results.

\section{Research developed}

\subsection{Materials and methods}

\subsubsection{Subjects}

This study was carried out in Portugal, in 80 workers occupationally exposed to formaldehyde vapours: 30 workers from formaldehyde and formaldehyde-based resins production factory and 50 from 10 pathology and anatomy laboratories. A control group of 85 non-exposed subjects was considered. All subjects were provided with the protocol and with the consent form, which they read and signed.

Health conditions, medical history, medication and lifestyle factors for all studied individuals, as well as information related to working practices (such as years of employment) were obtained through a standard questionnaire.

\subsubsection{Exposure assessment}

Two different exposure assessment methods were, simultaneously, applied in the 10 anatomy and pathology laboratories in Portuguese hospitals and in the formaldehyde and formaldehyde-based resins production factory, in order to assess formaldehyde occupational exposure. Environmental monitoring was performed between the period of September 2007 and March of 2008. 
In these two occupational settings were identified different exposure groups. In laboratories were defined three, namely pathologists, technicians and technical assistant. Also, in the factory were define three groups - production of resins, impregnation and quality control. These definitions were based essentially on activities similarity.

\subsubsection{Methods}

\section{Method 1}

In one of the methods 30 environmental samples were obtained by personal air sampling with low flow rate $(0.01$ to $0.10 \mathrm{~L} / \mathrm{min})$ pumps (Zambelli) during a typical working day. The sorbent tubes used were impregnated with $10 \%$ (2-hydroxymethyl)piperidine. Sampling time was 6 to 7 hours. Two to three samples were collected in each laboratory by the use of electric flow pumps which were placed in a worker of each exposure group.

Formaldehyde levels were measured by Gas Chromatography (GC). Capillary column: Supelcowax ${ }^{10}$ - $30 \mathrm{~m} \times 0.32 \mathrm{~mm} \times 0.5 \mu \mathrm{m}$; analyte: oxazolidine derivative of formaldehyde; desorption: $1 \mathrm{~mL}$ toluene; $60 \mathrm{~min}$ ultrasonic; injection volume: $1 \mu \mathrm{L}$ splitless; split vent time $30 \mathrm{sec}$; temperature: injector: $250{ }^{\circ} \mathrm{C}$, detector: $300{ }^{\circ} \mathrm{C}$, column: $70^{\circ} \mathrm{C}$ for $1 \mathrm{~min} ; 15^{\circ} \mathrm{C} / \mathrm{min}$; hold at $240^{\circ} \mathrm{C}$ for $10 \mathrm{~min}$; carrier gas: $\mathrm{He}-1.5 \mathrm{~mL} / \mathrm{min}$; calibration: formalin solution spiked on sorbent - $4.7 \mu \mathrm{g} / \mathrm{mL}, 6.0 \mu \mathrm{g} / \mathrm{mL}, 13.0 \mu \mathrm{g} / \mathrm{mL}, 25.0 \mu \mathrm{g} / \mathrm{mL}, 40.0 \mu \mathrm{g} / \mathrm{mL}, 50.0 \mu \mathrm{g} / \mathrm{mL}$, $100.0 \mu \mathrm{g} / \mathrm{mL}$ e $200.0 \mu \mathrm{g} / \mathrm{mL}$; calibration curve: $\mathrm{y}=0.008522 \mathrm{x}-0.008109 \mathrm{r}^{2}=0.999968$, LOD: $1 \mu \mathrm{g} /$ sample . Analysis and time-weighted average (TWA ${ }_{8 \mathrm{~h}}$ ) estimated according to the National Institute of Occupational Safety and Health method - NIOSH 2541 (National Institute of Occupational Safety and Health [NIOSH], 1994).

\section{Method 2}

Ceiling values for formaldehyde exposure were obtained using Photo Ionization Detection (PID) direct-reading equipment (with an $11.7 \mathrm{eV}$ lamp) designated by First-Check, from Ion Science. This equipment accurately detects formaldehyde from $1 \mathrm{ppb}$ to 10,000 ppm and performs automatically data log readings from the sensor on a second basis. Measurements were performed in each task and readings were stored in instrument internal memory with a date and time stamp. At the same time it was performed video recording and synchronized with real-time exposure data obtained with PID equipment followed by combination of the exposure profile with the video image of worker activity.

With this method it was possible to establish a relation between worker activities and ceiling values, and to determine principal emission sources.

Eighty three activities were studied in the 10 laboratories and three activities in the factory. All tasks were studied in normal conditions, namely using ventilation dispositive and, as usual, none of the workers was using masks to protect from formaldehyde vapours.

In both methods sampling/measures were performed near workers respiratory system.

Data obtained from NIOSH 2451 method was compared with reference value from OSHA (TLV-TWA $=0.75 \mathrm{ppm}$ ) because there is no reference in Portugal for this exposure metric. The ceiling values obtained from PID method were compared with reference value from Portuguese Norm 1796-2007 (0.3 ppm). 


\subsubsection{Biological monitoring}

To evaluate the effects of the occupational exposure, the study of effect biomarkers was conducted. The biomarkers of effect studied were specifically genotoxicity biomarkers, namely micronuclei in two different biological matrixes - peripheral blood lymphocytes and buccal exfoliated cells.

The protocol used to measure the MN in peripheral blood lymphocytes was the fully validated cytokinesis-blocked micronucleus assay (CBMN), developed by Fenech [20], where it is used citochalasin B to block the cytokinesis in order to lymphocytes had a binucleated appearance. Heparinized blood samples were obtained by venipuncture from all subjects and freshly collected blood was directly used for the MN test. Lymphocytes were isolated using FicollPaque gradient and placed in RPMI 1640 culture medium with L-glutamine and red phenol added with $10 \%$ inactivated fetal calf serum, $50 \mathrm{ug} / \mathrm{ml}$ streptomycin $+50 \mathrm{U} / \mathrm{mL}$ penicillin, and $10 \mathrm{ug} / \mathrm{mL}$ phytohaemagglutinin. Duplicate cultures from each subject were incubated at $37^{\circ} \mathrm{C}$ in a humidified $5 \% \mathrm{CO}_{2}$ incubator for $44 \mathrm{~h}$, and cytochalasin-b $6 \mathrm{ug} / \mathrm{mL}$ was added to the cultures in order to prevent cytokinesis. After $28 \mathrm{~h}$ incubation, cells were spun onto microscope slides using a cytocentrifuge. Smears were air-dried and double stained with May-GrünwaldGiemsa and mounted with Entellan. The frequencies of binucleated cells with MN were determined analyzing 1000 lymphocytes from two slides for each subject.

The optimal protocol of MN test for buccal exfoliated cells was performed after many experiments. In order to reach the optimal protocol, different techniques of collecting the cells and the staining were done.

Concerning to the sample collection, it was considered that the best way of obtaining the sample it was by scrapping the inner checks of the individuals with an endobrush and directly performed a smear in two slides. The samples were immediately fixed with Mercofix ${ }^{\circledR}$, a methanol based preservative.

The staining protocols selected were based on the affinity of the stains with the nucleus: Hematoxilin-Eosin, Hematoxilin, Giemsa, May-Grunwald Giemsa, Papanicolaou, Feulgen with Light Green and Feulgen.

The reliable results were achieved with Feulgen without counterstain (Nersesyan et al., 2006). This technique consists in a first step of hydrolysis with HCL 5M followed by washing with distillate water, incubation with Schiff Reagent and tap water final washing. The slides were allowed to air dried, mounted with entellan ${ }^{\circledR}$. Two thousand cells were scored from each individual. Only cells containing intact nuclei, neither clumped nor overlapping were included in the analysis.

The criteria for scoring the nuclear abnormalities in lymphocytes and $\mathrm{MN}$ in buccal cells were described by Fenech et al. (1999) and Tolbert et al. (1991), respectively.

\subsection{Results}

\subsubsection{Characteristics of the studied population}

The characterization of the population studied is summarized in Table 1. Controls and exposed workers did not differ significantly in age and in smoking habits. Only for gender distribution a significant difference was found between the two groups $(p=0.002)$, due to the larger number of women in the control group. 


\begin{tabular}{|l|c|c|c|}
\hline & Control Group & Exposed Group & $P$ value \\
\hline Number of subjects & 85 & 80 & \\
\hline Gender & $31(36.6 \%)$ & $48(60.0 \%)$ & 0.002 \\
Male & $54(63.5 \%)$ & $32(40.0 \%)$ & \\
Female & $20-55$ & $19-56$ & \\
\hline Age (years) & 33.87 & 35.74 & 0.180 \\
Range & 8.262 & 9.470 & 0.024 \\
Mean & $59(69.4 \%)$ & $55(68.8 \%)$ & 0.927 \\
St. Deviation & $26(30.6 \%)$ & $25(31.3 \%)$ & \\
\hline Smoking status & & $1-35$ & \\
Non-smokers & ----- & \\
Smokers & & \\
\hline Years of exposure & & \\
Range &
\end{tabular}

Table 1. Characterization of the studied population

None of the individuals presented relevant information about health conditions, medical history, medication and lifestyle factors that could influence the results of MN test.

\subsubsection{Exposure assessment}

Formaldehyde exposure values were determined using the above described methods: NIOSH 2541 for average concentrations $\left(\right.$ TWA $_{8 \mathrm{~h}}$ ) and PID method to obtain ceiling concentrations (Tables 2 and 3).

\begin{tabular}{|c|c|c|c|c|c|}
\hline Laboratories & Exposure Groups & $\begin{array}{c}\text { FA TWA } \\
\text { n=29 } \\
(\mathrm{ppm})\end{array}$ & $\begin{array}{c}\text { FA Ceiling } \\
\text { n=83 } \\
(\mathrm{ppm})\end{array}$ & $\begin{array}{c}\text { Range } \\
\text { Ceiling values } \\
(\mathrm{ppm})\end{array}$ & $\begin{array}{c}\text { Mean } \\
\text { Ceiling values } \\
(p p m)\end{array}$ \\
\hline \multirow[t]{3}{*}{ A } & Technical Assistant & 0.27 & 2.51 & $1.05-2.51$ & 1.78 \\
\hline & Pathologist & $<\mathrm{LOD}$ & 3.19 & $0.34-3.19$ & 1.04 \\
\hline & Technician & 0.16 & NM & --_---- & \\
\hline \multirow[t]{3}{*}{ B } & Technical Assistant & 0.15 & 0.62 & 0.62 & ----- \\
\hline & Pathologist & 0.24 & 2.71 & $1.49-3.36$ & 2.23 \\
\hline & Technician & 0.16 & 3.36 & $1.91-3.36$ & 2.31 \\
\hline \multirow[t]{3}{*}{ C } & Technical Assistant & 0.12 & 0.53 & 0.53 & ----- \\
\hline & Pathologist & 0.47 & 2.93 & $1.53-2.93$ & 2.18 \\
\hline & Technician & 0.51 & 2.28 & $2.22-2.28$ & 2.25 \\
\hline \multirow[t]{3}{*}{$\mathrm{D}$} & Technical Assistant & $<$ LOD & NM & ------ & \\
\hline & Pathologist & 0.07 & 2.31 & $2.09-2.31$ & 2.21 \\
\hline & Technician & 0.11 & 0.85 & 0.85 & ----- \\
\hline \multirow[t]{3}{*}{$\mathrm{E}$} & Technical Assistant & $<$ LOD & NM & ----- & ----- \\
\hline & Pathologist & 0.06 & 1.10 & $0.95-1.10$ & 1.03 \\
\hline & Technician & 0.07 & 0.85 & 0.85 & ---- \\
\hline \multirow[t]{3}{*}{$F$} & Technical Assistant & 0.09 & NM & ----- & ----- \\
\hline & Pathologist & 0.23 & 0.34 & $0.22-0.34$ & 0.28 \\
\hline & Technician & 0.12 & 0.28 & 0.28 & ----- \\
\hline
\end{tabular}




\begin{tabular}{|c|c|c|c|c|c|}
\hline Laboratories & Exposure Groups & $\begin{array}{c}\text { FA TWA } \mathbf{T h} \\
\mathrm{n}=29 \\
(\mathrm{ppm})\end{array}$ & $\begin{array}{c}\text { FA Ceiling } \\
\text { n=83 } \\
(\mathrm{ppm})\end{array}$ & $\begin{array}{c}\text { Range } \\
\text { Ceiling values } \\
(\mathrm{ppm})\end{array}$ & $\begin{array}{c}\text { Mean } \\
\text { Ceiling values } \\
(p p m)\end{array}$ \\
\hline \multirow[t]{3}{*}{ G } & Technical Assistant & 0.16 & 0.71 & $0.64-1.71$ & 0.67 \\
\hline & Pathologist & 0.05 & 2.81 & $0.18-2.81$ & 0.56 \\
\hline & Technician & 0.04 & 1.26 & 1.26 & ---- \\
\hline \multirow[t]{3}{*}{$\mathrm{H}$} & Technical Assistant & 0.25 & 0.68 & 0.68 & ---- \\
\hline & Pathologist & 0.11 & 2.08 & $1.21-2.08$ & 1.65 \\
\hline & Technician & 0.25 & 0.68 & 0.68 & ---- \\
\hline \multirow[t]{3}{*}{ I } & Technical Assistant & 0.05 & 0.95 & 0.95 & ---- \\
\hline & Pathologist & $<$ LOD & 0.47 & $0.21-0.47$ & 0.34 \\
\hline & Technician & 0.06 & NM & ---- & ---- \\
\hline \multirow[t]{3}{*}{ J } & Technical Assistant & NM & NM & ---- & ---- \\
\hline & Pathologist & 0.13 & 5.02 & $1.15-5.02$ & 3.24 \\
\hline & Technician & 0.08 & 4.32 & 4.32 & ---- \\
\hline
\end{tabular}

${ }^{*}$ Higher values for each exposure group

$<$ LOD - Below the Detection limit

FA-formaldehyde

NM - Not measured

Table 2. Formaldehyde exposure results in laboratories

\begin{tabular}{|c|c|c|c|c|}
\hline Exposure groups & $\begin{array}{c}\text { FA } \\
\text { TWA }_{8 \mathbf{h}} \\
\mathrm{n}=3 \\
(\mathrm{ppm})\end{array}$ & $\begin{array}{c}\text { FA Ceiling * } \\
\mathrm{n}=3 \\
(\mathrm{ppm})\end{array}$ & $\begin{array}{c}\text { Range } \\
\text { Ceiling } \\
\text { values } \\
(\mathrm{ppm})\end{array}$ & $\begin{array}{c}\text { Mean } \\
\text { Ceiling } \\
\text { values } \\
(\mathrm{ppm})\end{array}$ \\
\hline $\begin{array}{c}\text { Production of } \\
\text { resins }\end{array}$ & $\mathrm{NM}$ & $\begin{array}{c}\text { Collecting a sample of the reactor } \\
1.02\end{array}$ & $0.01-1.02$ & 0.15 \\
\hline Impregnation & $<$ LOD & $\begin{array}{c}\text { Operation of impregnation machine } \\
1.04\end{array}$ & $0.00-1.04$ & 0.21 \\
\hline Quality control & $<$ LOD & $\begin{array}{c}\text { analyze a resin sample } \\
0.52\end{array}$ & $0.01-0.52$ & 0.08 \\
\hline
\end{tabular}

* Higher values for each exposure group

$<$ LOD - Below the Detection limit

NM - Not measured

FA -formaldehyde

Table 3. Formaldehyde exposure results in the factory

All of the results for time-weighted average concentrations $\left(\mathrm{TWA}_{8 \mathrm{~h}}\right.$ ) not exceeded OSHA reference value $(0.75 \mathrm{ppm})$, with the majority of values falling below the method detection limited.

On the opposite, for ceiling concentrations all the higher results obtained for each exposure group in each occupational setting exceeded the reference value $(0.3 \mathrm{ppm})$. In laboratories, values lied between $0.18 \mathrm{ppm}$ and $5.02 \mathrm{ppm}$, with a mean of $2.52 \mathrm{ppm}$. In the factory the concentration values registered each second lied between 0.0 and $1.02 \mathrm{ppm}$. 
The three activities studied in the factory have result above the reference value for ceiling concentrations (0.3 ppm).

In production of resins the higher concentration value was obtained during the collection of a sampling in resins reactor performed by a production operator. In this case and during operation of impregnation machine there were not local exhaust ventilation dispositive. Only in the "quality control" exposure group there was a small hotte that is not normally used to perform quality analysis of resins.

In the case of laboratories, all of them had, at least, one task with a higher result than the reference value $(0.3 \mathrm{ppm})$ (Figure 1$)$.

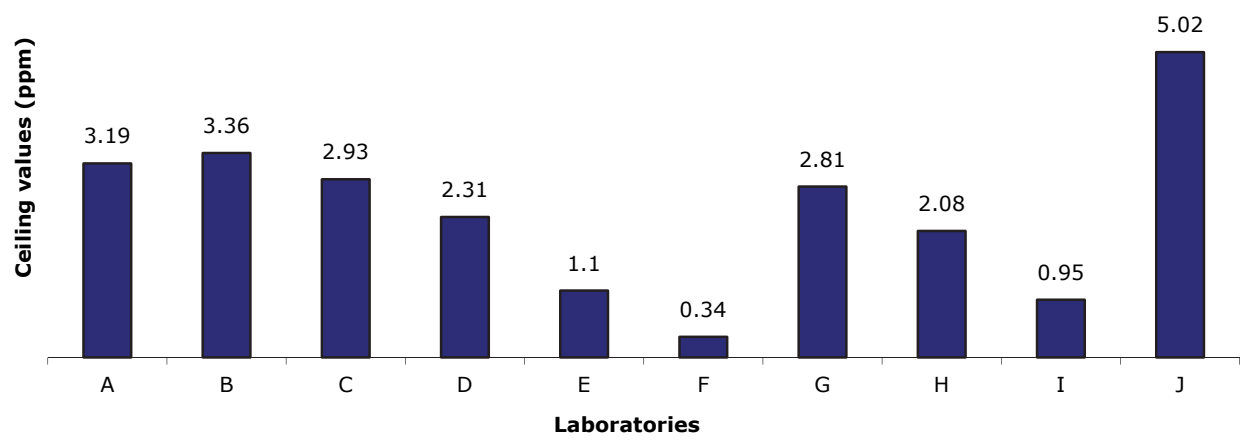

Fig. 1. Higher ceiling value obtained in each laboratory

Considering all of the 83 tasks studied in the laboratories (Table 4 ), $93 \%$ of the results were higher than the reference value for ceiling concentrations (0.3 ppm).

Highest exposure level was observed during "macroscopic examination" of formaldehydepreserved specimens. This task is developed in a macroscopic bench with local exhaust ventilation. In all the laboratories studied was verified that ventilation was functioning normally.

The task "data registration" showed also a high formaldehyde concentration value, being important to note that this task occurs during macroscopic examination (Table 4).

Concerning the 69 macroscopic examinations, the most frequent task develop in this laboratories, it was possible to verify that near $93 \%$ of formaldehyde concentration values were higher than $0.3 \mathrm{ppm}$.

In this occupational setting, highest score for ceiling values was identified in the results of the exposure group "Pathologists" and the highest mean was obtained for the "Technicians" group (Table 5).

It is important to consider that none of the workers of the two occupational settings were using appropriate respiratory protection during the tasks studied. 


\begin{tabular}{|l|c|c|l|l|}
\hline Tasks & Number & $\begin{array}{l}\text { Ceiling } \\
\text { Values } \\
(\mathrm{ppm})\end{array}$ & Exposed Workers \\
\hline Macroscopic examination & 69 & 5.02 & Pathologist & \\
\hline $\begin{array}{l}\text { Disposal of specimen and used } \\
\text { solutions }\end{array}$ & 5 & 0.95 & $\begin{array}{l}\text { Technicians and Technical } \\
\text { Assistant }\end{array}$ \\
\hline Jar filling & 2 & 2.51 & Technical Assistant \\
\hline Data registration & 3 & 4.32 & Technicians \\
\hline Specimen wash & 2 & 2.28 & Technicians \\
\hline Biopsy & 2 & 1.91 & Technicians \\
\hline
\end{tabular}

Table 4. Formaldehyde exposure during laboratories tasks

\begin{tabular}{|l|c|c|c|c|}
\hline $\begin{array}{l}\text { Exposure } \\
\text { Groups }\end{array}$ & Tasks studied & $\begin{array}{c}\text { Range } \\
(\mathrm{ppm})\end{array}$ & $\begin{array}{c}\text { Mean } \\
(\mathrm{ppm})\end{array}$ & $\begin{array}{c}\text { St. Deviation } \\
(\mathrm{ppm})\end{array}$ \\
\hline Technical Assistant & 9 & $0.28-2.51$ & 0.86 & 0.58 \\
\hline Pathologist & 65 & $0.21-5.02$ & 1.42 & 1.07 \\
\hline Technician & 14 & $0.68-4.32$ & 2.04 & 0.95 \\
\hline
\end{tabular}

* some activities involved the simultaneously exposure of two groups

Table 5. Ceiling results for each exposure group

\subsubsection{Biological monitoring}

Table 6 showed that the frequency of $\mathrm{MN}$ in occupationally exposed workers was significantly higher in comparison with the control group, both in peripheral blood lymphocytes $(\mathrm{p}<0.001)$ and in epithelial buccal cells $(\mathrm{p}<0.001)$.

\begin{tabular}{|c|c|c|c|c|}
\hline & Controls & \multicolumn{3}{|c|}{ Exposed } \\
\cline { 2 - 5 } & & Factory & $\begin{array}{c}\text { Pathology and anatomy } \\
\text { laboratories }\end{array}$ & Total \\
\hline $\begin{array}{c}\text { MN PBL 1 } \\
\text { Mean } \pm \text { Std. Dev }\end{array}$ & $1.17 \pm 1.95$ & $1.76 \pm 2.07$ & $3.70 \pm 3.86$ & $2.97 \pm 3.42$ \\
\hline $\begin{array}{c}\text { MN EBC } 2 \\
\text { Mean } \pm \text { Std. Dev }\end{array}$ & $0.13 \pm 0.48$ & $1.27 \pm 1.55$ & $0.64 \pm 1.74$ & $0.88 \pm 1.69$ \\
\hline
\end{tabular}

${ }^{1}$ Peripheral Blood Lymphocytes

2 Epithelial Buccal Cells

Table 6. Frequency of MN in the studied population

When analyzing each occupational setting separately, we found significant differences in MN frequencies in peripheral blood lymphocytes $(\mathrm{p}<0.001)$ and in epithelial buccal cells $(p<0.005)$ between the laboratories and control groups. Concerning the factory group, 
significant differences in $\mathrm{MN}$ frequencies were only detected in epithelial buccal cells $(\mathrm{p}<0.001)$.

Finally, it was compared MN frequencies between the two exposed groups and found that MN frequency in peripheral blood lymphocytes was significantly higher in the laboratories group $(\mathrm{p}<0.005)$, but respecting to epithelial buccal cells there was no significant difference between them $(p=0.108)$.

In what concern to the three exposure groups studied in the pathology anatomy laboratories, the pathologists group has higher MN mean in lymphocytes and the technician had higher MN mean in buccal cells (Table 7).

\begin{tabular}{|c|c|c|c|}
\hline \multirow{2}{*}{} & \multicolumn{3}{|c|}{$\begin{array}{c}\text { Pathology and anatomy } \\
\text { laboratories }\end{array}$} \\
\cline { 2 - 4 } & Pathologist & Technician & Technical Assistant \\
\hline $\begin{array}{c}\text { MN PBL } \\
\text { Mean } \pm \text { Std. Error of Mean }\end{array}$ & $5.00 \pm 1.24$ & $3.76 \pm 0.647$ & $4.13 \pm 1.55$ \\
\hline $\begin{array}{c}\text { MN EBC } \\
\text { Mean } \pm \text { Std. Error of Mean }\end{array}$ & $0.58 \pm 0.434$ & $1.18 \pm 0.406$ & $0.88 \pm 0.611$ \\
\hline
\end{tabular}

Table 7. Frequency of MN in the exposure groups of laboratories

Factory results reveal quality control group with higher MN mean in lymphocytes and also in buccal cells (Table 8 ).

\begin{tabular}{|c|c|c|c|}
\hline & \multicolumn{3}{|c|}{ Factory } \\
\cline { 2 - 4 } & Resins Production & Impregnation & Quality control \\
\hline $\begin{array}{c}\text { MN PBL } \\
\text { Mean } \pm \text { Std. Error of Mean }\end{array}$ & $1.85 \pm 2.48$ & $1.16 \pm 1.04$ & $4.5 \pm 0.7$ \\
\hline $\begin{array}{c}\text { MN EBC } \\
\text { Mean } \pm \text { Std. Error of Mean }\end{array}$ & $0.66 \pm 0.94$ & $1.75 \pm 1.79$ & $3.5 \pm 0.5$ \\
\hline
\end{tabular}

Table 8. Frequency of $\mathrm{MN}$ in the exposure groups of factory

\subsection{Discussion}

As indicated by several studies (IARC, 2006; Orsière et al., 2006; Shaham et al., 2003) exposure assessment in present investigation demonstrates that both occupational settings studied involve exposure to high peak formaldehyde concentrations.

The importance of this consideration lies in the fact that health effects (cancer) linked to formaldehyde exposure are more related with peaks of high concentrations than with long time exposure at low levels (IARC, 2006; Pyatt et al., 2008). Moreover, the choice of exposure metric should be based on the most biologically relevant exposure measure in order to diminish misclassification of exposure, thus leading to attenuated exposure-response relationships (Preller et al., 2004). Furthermore, high exposures of short duration (peaks) are of special concern, because they can produce an elevated dose rate at target tissues and organs, potentially altering metabolism, overloading protective and repair mechanisms and 
amplifying tissue responses (Preller et al., 2004; Smith, 2001). In addition, Pyatt et al. (2008) pointed out, as a limitation in most epidemiological studies, the lack of data about exposure to peak concentrations. Therefore, in those studies, health effects resulting from occupational exposure to formaldehyde are associated to exposure exclusively based on time-weighted average concentrations (Pyatt et al., 2008). Until 2004 only two studies concerning the association between exposure to formaldehyde and nasopharyngeal cancer that presented data on exposure to ceiling concentrations obtained higher relative risk values compared with the other studies (Hauptmann et al., 2004; Pinkerton et al., 2004; Zhang et al., 2009).

Recently Hauptmann and colleagues have found that mortality rate from leukemia increased significantly not just with number of years of activity, in this case embalming, but also with increasing peak formaldehyde exposure (Dreyfuss, 2010; Hauptmann et al., 2009).

Results in laboratories indicate "macroscopic examination" as the task involving the highest exposure. This is probably because precision and very good visibility is needed and, therefore, pathologists must lean over the specimen with consequent increase of proximity to formaldehyde emission sources. Studies developed by Goyer et al., (2004) and Orsière et al., (2006) support that proximity to impregnated specimens promotes higher exposure to formaldehyde. "Pathologist" is normally the exposure group that performs this task. However, the "Technician" group obtained, simultaneously, higher TWA $\mathrm{Th}_{8 \mathrm{~h}}$ and higher mean of ceiling values. This can be due to the fact that this is the group envolved in more tasks related with formaldehyde exposure, during the working day.

In the case of the factory, the task "collecting a sample of the reactor" involved a manual process. Probably the proximity and reactor open promote exposure.

It is important to refer that these type of information (exposure determinants, emission sources and exposed workers) was only possible to obtain because video recording could be performed simultaneously with concentration measurements.

This resource gives opportunity to directly relate performance with exposure (Mcglothlin, 2005; Ryan et al., 2003; Rosén et al., 2005). Additionally, real-time measurements are useful also for evaluating engineering controls and their efficacy (Yokel \& MacPhail, 2011).

In addition, and in agreement with other studies (Kromouht, 2002; Meijster et al., 2008; Susi \& Schneider, 1995), it is possible to conclude that TWA $_{8 \mathrm{~h}}$ measurements give poor information and is of less utility in the identification of tasks that should be targeted for control.

Long exposures to formaldehyde, as those to which some workers are subjected for occupational reasons, are suspected to be associated with genotoxic effects that can be evaluated by biomarkers (Conaway et al., 1996; IARC, 2006; Viegas \& Prista, 2007). In this study, the results suggest that workers in pathological anatomy laboratories are exposed to formaldehyde levels that exceed recommended exposure criteria and a statistically significant association was found between formaldehyde exposure and biomarkers of genotoxicity, namely MN in lymphocytes and buccal cells. 
Chromosome damage and effects upon lymphocytes arise because formaldehyde escapes from sites of direct contact, such as mouth, originating nuclear alterations in lymphocytes of those exposed (He \& Jin, 1998; Orsière et al., 2006; Ye et al., 2005; Zhang et al., 2009).

Our results corroborate previous reports (Ye et al., 2005) that lymphocytes can be compromised by long term exposures. Moreover, the changes in peripheral lymphocytes can be a sign that the cytogenetic effects triggered by formaldehyde can reach tissues faraway from the site of initial contact (Suruda et al., 1993). Long term exposures to high concentrations of formaldehyde indeed appear to have a potential for generalized DNA damage. In experimental studies with animals, local genotoxic effects following formaldehyde exposure have been previously demonstrated to give rise to DNA-protein cross links, structural chromosomal aberrations, and aberrant cells (IARC, 2006). In our research work the $\mathrm{MN}$ frequency in peripheral blood lymphocytes was significantly higher in the laboratories group in comparison with the factory, probably because the years of exposure are higher in the first group.

In humans, formaldehyde exposure is associated with an increase in the frequency of $\mathrm{MN}$ in buccal epithelium cells (Burgaz et al., 2002; Speit et al., 2007) as corroborated by the results presented here.

Suruda el al. (1993) claims that although changes in oral and nasal epithelial cells and peripheral blood cells do not indicate a direct mechanism leading to carcinogenesis, they do indicate that DNA alterations took place. It thus appears reasonable to conclude that formaldehyde is a risk factor for those that are occupationally exposed in these two occupational settings (IARC, 2006).

In human biomonitoring studies it is important to assess the influence of major confounding factors such as gender, age and smoking habits in the endpoints studied. However, in ours results no significant differences were obtained in $\mathrm{MN}$ frequencies between women and men (both in peripheral blood lymphocytes and epithelial buccal cells). However, in other studies an increase in MN frequencies in women was found. Current knowledge on the effect of gender on genetic damage determines a 1.5-fold greater MN frequency in females than in males (Fenech et al., 2003; Wojda et al., 2007), witch can be explained by preferential aneugenic events involving the X-chromossome. Surralés et al. (1996) reported an excessive overrepresentation of this chromosome in micronucleic lymphocytes cultured from women.

Tobacco smoke contains a high number of mutagenic and carcinogenic substances and is causally linked to an elevated incidence of several forms of cancers (IARC, 1985). Hence, smoking is an important variable to consider in biomonitoring studies and, particularly in this study since formaldehyde is present in tobacco smoke (IARC, 2006). The effect of tobacco smoking on $\mathrm{MN}$ frequency in human cells has been object of study. In most reports the results were unexpected, as in many instance smokers had lower frequencies of MN than non-smokers (Bonassi et. 2003; Orsière et al., 2006). In the present study no significant differences were found in MN (peripheral blood lymphocytes and epithelial buccal cells) between smokers and non-smokers. These findings are similar to results obtained in the study of Bonassi et al., (2003). These authors recommend that quantitative data about smoking habit should be collected because the sub-group of heavy smokers ( $\geq 30$ cigarettes per day) can influence the results. For notice, the questionnaire results of this study revealed no heavy smokers in these two workers groups. 


\section{Conclusion}

Some preventive measures can be applied to reduce exposure to formaldehyde in these two occupational settings. In the case of anatomy and pathology laboratories exposure reduction can be achieved by the use of adequate local exhausts ventilation, relocation of the specimen containers to areas with isolated ventilation and using hooded enclosures over such containers.

For the factory, preventive measures must consider automating some processes like sampling in reactors and, additionally, promote the use of the existing located ventilation dispositive.

Exposure assessment methods applied in the research developed permitted to conclude that TWA $_{8 \mathrm{~h}}$ measurements give poor information concerning to preventive measures priority and CBMN assay applied to assess genotoxic effects is a screening technique that can be used for clinical prevention and management of workers under occupational carcinogenic risks, namely exposure to a genotoxic agent such as formaldehyde.

The most recent studies suggest that future research is warranted to more effectively assess the risk of leukemia arising from formaldehyde exposure and to better explain some inconsistencies in mode of action and, also, to understand the role of short-term peak exposures.

\section{References}

Agency for Toxic Substances and Disease Registry (ATSDR) (1999). Toxicological Profile for Formaldehyde. US Department Of Health And Human Services, Public Health Service.

Armstrong, R., Imrey, P., Lye, M., Armstrong, M., Yu, M. \& Sani, S. (2000). Nasopharyngeal carcinoma in Malaysian Chinese: occupational exposures to particles, formaldehyde and heat. Int J Epidemiol, 29,991-998.

Arts, J. Rennen, M. \& de Heer, C. (2006). Inhaled formaldehyde: evaluation of sensory irritation in relation to carcinogenicity. Regul. Toxicol. Pharmacol. 44, 144-160.

Arts, J., Muijser, H., Kuper, C., \& Woutersen, R. (2008). Setting an indoor air exposure limit for formaldehyde: Factors of concern. Regulatory Toxicology and Pharmacology, 52, 189-194

Baan, R., Grosse, Y., Straif, K., Secretan, B., El Ghissassi, F., Bouvard, V., Benbrahim-Tallaa, L., Guha, N., Freeman, C., Galichet, L. \& Cogliano V. (2009). On behalf of the WHO International Agency for Research on Cancer Monograph Working Group, A review of human carcinogens. Part F. Chemical agents and related occupations. The Lancet Oncol., 10, 1143-1144.

Bonassi, S., Fenech, M., Lando, C., Lin, YP., Ceppi, M., Chang, WP., Holland, N., KirschVolders, M., Zeiger, E., Ban, S., Barale, R., Bigatti, MP., Bolognesi, C., Jia, C., Di Giorgio, M., Ferguson, LR., Fucic, A., Lima, OG., Hrelia, P., Krishnaja, AP., Lee, TK., Migliore, L., Mikhalevich, L., Mirkova, E., Mosesso, P., ,Müller, WU., Odagiri, Y., Scarffi, MR., Szabova, E., Vorobtsova, I., Vral, A. \& Zijno, A. (2001). Human MicroNucleus Project: international database comparison for results with the cytokinesis-block micronucleus assay in human lymphocytes: I. Effect of laboratory 
protocol, scoring criteria, and host factors on the frequency of micronuclei. Environ Mol Mutagen, 37, 31-45.

Burgaz, S., Erdem, O., Çakmak, G. \& Karakaya, A. (2002). Cytogenetic analysis of buccal cells from shoe-workers and pathology and anatomy laboratory workers exposed to n-hexane, toluene, methyl ethyl ketone and formaldehyde. Biomarkers., 2, 151161.

Chen, J., So, S., Lee, H., Fraser, MP., Curl, R., Harman, T. \& Tittel, F. (2004). Atmospheric Formaldehyde Monitoring in the Greater Houston Area in 2002. Applied Spectroscopy, 58, 2.

Coggon, D., Harrism EC., Poole, J. \& Palmer, KT. (2003). Extended follow-up of a cohort of British chemical workers exposed to formaldehyde. J Natl Cancer Inst, 95, 1608-1615.

Cogliano, V., Grosse, Y., Baan, R.A., Straif, K., Secretan, M.B. \& El Ghissassi, F. (2005). Meeting report: summary of IARC monographs on formaldehyde, 2butoxyethanol, and 1-tert-butoxy-2-propanol, Environ. Health Perspect. 113, 12051208.

Cole, P. \& Axten, C. (2004). Formaldehyde and leukemia: an improbable causal relationship. Regul. Toxicol. Pharmacol. 40, 107-112.

COMEAP, Guidance on the Effects of Health of Indoor Air Pollutants, Committee on the Medical Effects of AirPollutants (2004). Available from:

http://www.advisorybodies.doh.gov.uk/comeap/PDFS/guidanceindoorairqualit ydec04.pdf.

Conaway, C., Whysner, J., Verna, L. \& Williams, G. (1996). Formaldehyde mechanistic data and risk assessment: endogenous protection from DNA adduct formation. Pharmacol. Ther., 71, $29-55$.

Casanova, M., Heck, H.D., Everitt, J.I., Harrington, W.W.J. \& Popp, J.A. (1988). Formaldehyde concentrations in the blood of rhesus monkeys after inhalation exposure. Food Chem. Toxicol. 26, 715-716.

Dreyfuss, J. (2010) Occupational formaldehyde exposure linked to increased risk of myeloid leukemia and death. A Cancer Journal for Clinicians, 60, 135-136.

Fenech, M., Holland, N., Chang, W., Zeiger, E. \& Bonassi, S. (1999). The Human MicroNucleus Project - An international collaborative study on the use of micronucleus technique for measuring DNA damage in humans. Mutat. Res., 428, $271-283$.

Fenech, M., Chang, WP., Kirsch-Volders, M., Holland, N., Bonassi, S. \& Zeiger, E. (2003). HUman MicronNucleus project: HUMN project: detailed description of the scoring criteria for the cytokinesis-block micronucleus assay using isolated human lymphocyte cultures. Mutat Res, 534, 65-75.

Goyer, N., Beaudry, C., Bégin, D., Bouchard, M., Buissonnet, S., Carrier, G., Gely, O., Gérin, M., Lavoué, J., Lefebvre, P., Noisel, N., Perrault, G. \& Roberge, B. (2004). Impacts d'un abaissement de la valeur d'exposition admissible au formaldéhyde : industries de fabrication de formaldéhyde et de résines à base de formaldéhyde. Montréal : Institut de Recherche Robert-Sauvé en Santé et en Sécurité du Travail.

Granby, K., Christensen, CS. \& Lohse, C. (1997). Urban and semi-rural observations of carboxylic acids and carbonyls. Atmospheric Environment. 31, 10, 1403-1415. 
Hauptmann, M., Lubin, JH., Stewart, PA., Hayes, RB. \& Blair, A. (2003). Mortality from lymphohematopoietic malignancies among workers in formaldehyde industries. J. Natl. Cancer Inst. 95, 1615-1623.

Hauptmann, M., Lubin, JH., Stewart, PA., Hayes, RB. \& Blair, A. (2004). Mortality from solid cancers among workers in formaldehyde industries. Am J Epidemiol., 159, 1117-1130.

Hauptmann, M., Stewart, PA., Lubin, JH., Beane Freeman, LE., Hornung, RW., Herrick, RF., Hoover, RN., Fraumeni, JF Jr., Blair, A. \& Hayes, RB. (2009). Mortality from lymphohematopoietic malignancies and brain cancer among embalmers exposed to formaldehyde. J Natl Cancer Inst., 101, 24, 1696-708.

He, J-L. \& Jin, H.-Y. (1998). Detection of cytogenetic effects in peripheral lymphocytes of students exposed to formaldehyde with cytokinesis-blocked micronucleus assay. Biomed. Environm. Sci., 11, 87-92.

Heck, H.D., Casanova-Schmitz, M., Dodd, P.B., Schachter, E.N., Witek, T.J. \& Tosun, T. (1985). Formaldehyde (CH2O) concentrations in the blood of humans and Fischer344 rats exposed to $\mathrm{CH} 2 \mathrm{O}$ under controlled conditions. Am. Ind. Hyg. Assoc. J., 46, $1-3$.

Heck, H. \& Casanova, M. (2004). The implausibility of leukemia induction by formaldehyde: a critical review of the biological evidence for distant-site toxicity. Regul. Toxicol. Pharmacol., 40, 92-106.

Hildesheim, A., Dosemeci, M., Chan, CC., Chen, CJ., Cheng, YJ., Hsu, MM., Chen, IH., Mittl, BF., Sun, B., Levine, PH., Chen, JY., Brinton, LA. \& Yang, CS. (2001). Occupational exposure to wood, formaldehyde, and solvents and risk of nasopharyngeal carcinoma. Cancer Epidemiol Biomarkers Prev., 10, 1145-1153.

International Agency for Research on Cancer (IARC). (2006). Formaldehyde, 2-Butoxyethanol and 1-tert-Butoxypropan-2-ol. Lyon : IARC.

International Agency for Research on Cancer (IARC). (1985). Tobacco Habits Other Than Smoking Betel-Quid and Areca-Nut Chewing and Some Related Nitrosamines. Lyon : IARC.

International Programme on Chemical Safety (IPCS). (1991). Formaldehyde : health and safety guide. Geneva : World Health Organization. Available from: http://www.inchem.org/documents/hsg/hsg/hsg057.htm.

Kinney, P.L., Chillrud, S.N., Ramstrom, S., Ross, J. \& Spengler, J.D. (2002). Exposures to multiple air toxics in New York City. Environ. Health Perspect., 110 (Suppl. 4), 539546.

Kromouht, H. (2002). Design of measurement strategies for workplace exposures. Occup Environ Med., 59, 349-354.

Lubin, M., Stewart, JH., Hayes, PA. \& Blair, RB. (2004). Mortality from solid cancers among workers in formaldehyde industries. Am J Epidemiol., 159, 1117-1130.

Marsh, G.M. \& Youk, A.O. (2004). Reevaluation of mortality risks from leukemia in the formaldehyde cohort study of the National Cancer Institute. Regul. Toxicol.Pharmacol. 40, 113-124.

Meijster, T., Tielemans, E., Schinkel, J. \& Heederik, D. (2008). Evaluation of peak exposures in the Dutch flour processing industry: implications for intervention strategies. Ann Occup Hy., 52, 587-596. 
Mcglothlin JD. (2005). Occupational exposure assessment and control using video exposure monitoring in the pharmaceutical industry. Proceedings of International Scientific Conference (IOHA 2005), Pilanesberg National Park North West Province, South Africa. Pilanesberg September 2005.

Merk, O. \& Speit, G. (1998). Significance of formaldehyde-induced DNA-protein crosslinks for mutagenesis. Environ Mol Mutagen, 32, 260-268.

NATIONAL INSTITUTE FOR OCCUPATIONAL SAFETY AND HEALTH (NIOSH) NIOSH manual of analytical methods: DHHS (NIOSH) Publication 94-113. $4^{\text {th }}$ ed. Atlanta, GA: Centers for Disease Control and Prevention, 1994.

Nazaroff, W., Coleman, BK., Destaillats, H., Hodgson, AT., Liu, D., Lunden, MM., Singer, BC. \& Weschler, CJ. (2006). Indoor air chemistry: cleaning agents, ozone and toxic air contaminants. Berkeley, CA: Air Resources Board, California Environmental Protection Agency.

Nersesyan, A., Kundi, M., Atefie, K., Schulte-Hermann \& R. Knasmüller, S. (2006). Effect of staining perocedures on the results of micronucleus assays with exfoliated oral mucosa cells. Cancer Epidemiol Biomarkers Prev., 15, 1835 - 1840.

Odabasi, M. \& Seyfioglu, R. (2005). Phase partitioning of atmospheric formaldehyde in a suburban atmosphere. Atmospheric Environment. 39, 28, 5149-5156.

Ohura, T., Amagai, T., Senga, Y. \& Fusaya, M. (2006). Organic air pollutants inside and outside residences in Shimizu, Japan: levels, sources and risks. Sci. Total Environ. 366, 485-499.

Orsière, T., Sari-Minodier, I., Iarmarcovai, G. \& Botta, A. (2006). Genotoxic risk assessment of pathology and anatomy laboratory workers exposed to formaldehyde by use of personal air sampling and analysis of DNA damage in peripheral lymphocytes. Mutat Res., 605, 30-41.

Pinkerton, LE., Hein, MJ. \& Stayner, LT. (2004). Mortality among a cohort of garment workers exposed to formaldehyde: an update. Occup. Environ. Med. 61, 193-200.

Preller, L., Burstyn, I., De Pater, N. \& Kromhout, H. (2004). Characteristics of Peaks of Inhalation Exposure to Organic Solvents. Ann Occup Hyg., 48, 643-652.

Pyatt, D., Natelson, E. \& Golden, R. (2008). Is inhalation exposure to formaldehyde a biologically plausible cause of lymphohematopoietic malignancies? Regulatory Toxicology and Pharmacology, 51, 119-133.

Rosén, G., Andersson, IM., Walsh, PT., Clark, RD., Säämänen, A., Heinonen, K., Riipinen, H. \& Pääkkönen, R. (2005). A review of video exposure monitoring as an occupational hygiene tool. Annals of Occupational Hygiene., 1-17.

Ryan, TJ., Burroughs, GE., Taylor, K. \& Kovein, RJ. (2003).Video exposure assessments demonstrate excessive laboratory formaldehyde exposures. Applied Occupational and Environmental Hygiene., 18, 450-457.

SAC, Standardization Administration of China: Indoor Air Quality Standard. (2002). http://www.sac.gov.cn/templet/english/zmCountryBulletinByNoEnglish.do?cou ntryBulletinNo=20021248.

Schwilk, E., Zhang, L., Smith, M., Smith, A. \& Steinmaus, C. (2010) Formaldehyde and Leukemia: an updated meta-analyses and evaluation of bias. Journal of Occupational and Environmental Medicine, 52, 878-886. 
Shaham, J., Bomstein, Y., Gurvich, R., Rashkovsky, M. \& Kaufman, Z. (2003). DNA-protein crosslinks and p53 protein expression in relation to occupational exposure to formaldehyde. Occup Environ Med., 60, 403-409.

Smith, T. (2001). Studying peak exposure: toxicology and exposure statistics. In: Marklund S., editor. X2001 - Exposure assessment in epidemiology and practice. Stockholm: National Institute for Working Life, 207-209.

Speit, G. \& Schmid, O. (2006). Local genotoxic effects of formaldehyde in humans measured by the micronucleus test with exfoliated cells. Mutat. Res., 613, 1-9.

Speit, G., Schmid, O., Fröhler-Keller, M., Lang, I. \& Triebig, G. (2007). Assessment of local genotoxic effects of formaldehyde in humans measured by de micronucleus test with exfoliated buccal mucosa cell. Mutation Research, 627, 129-131.

Surrallés, J., Falck, G. \& Norppa, H. (1996). In vivo cytogenetic damage revealed by FISH analysis of micronuclei in uncultured human T lymphocytes. Cytogenet Cell Genet., 75, 151-154.

Suruda, A., Schulte, P., Boeniger, M., Hayes, RB., Livingston, GK., Steenland, K., Stewart, P., Herrick, R. ,Douthit, D. \& Fingerhut, MA. (1993) Cytogenetic effects of formaldehyde exposure in students of mortuary science. Cancer Epidemiol Biomarkers Prev., 2, 453-460.

Susi, P. \& Schneider, S. (1995). Database needs for a task-based exposure assessment model for construction. Applied Occupational Environmental Hygiene., 10, 394-399.

Tolbert, P., Shy, C. \& Allen, J. (1991). Micronuclei and other nuclear abnormalities in buccal smears: a field test in snuff users, Am. J. Epidemiol., 8, 840 - 850.

United States Environmental Protection Agency (USEPA). (2007). Indoor Air Quality (IAQ). Environmental Protection Agency. Available from: http://www.epa.gov/iaq/formalde.html.

Vaughan, TL., Stewart, PA., Teschke, K., Lynch, CF., Swanson, GM. \& Lyon, JL. Berwick, M. (2000) Occupational exposure to formaldehyde and wood dust and nasopharyngeal carcinoma. Occup Environ Med., 57, 376-384.

Viegas, S. \& Prista, J. (2007). Cancro Nasofaríngeo e Exposição a Formaldeído: avaliação da história profissional em 63 casos registados. Soc. Portuguesa de Medicina do Trabalho, $6,13-22$.

Viegas, S. \& Prista, J.(2010). Formaldehyde in Indoor Air: A Public Health Problem? in Air Pollution XVIII. 297-304. WIT Transactions on Biomedicine and Health. ISBN: 978-184564-450-5.

Vincent, R. \& Jandel, B. (2006). Exposition professionnelle au formaldéhyde en France: informations fournies par la base de données Colchic. Hygiène et sécurité du travail. Cahiers de notes documentaires. 19-33.

WHO-ROE, Regional Office of Europe (2006). Development of WHO Guidelines for Indoor Air Quality World Health Organization. Available from: http://www.euro.-who.int/Document/AIQ/IAQ_mtgrep_Bonn_Oct06.pdf.

Wojda, A., Zietkiewicz, E. \& Witt, M. (2007). Effects of age and gender on micronucleus and chromosome nondisjunction frequencies in centenarians and younger subjects. Mutagenesis, 22, 195-200.

Yao, X., Wang, W., et al. (2005). Seasonal change of formaldehyde concentration in the air of newly decorated houses in some cities of China. J. Environ. Health, 22, 353-355. 
Ye, X., Yan, W., Zhao, M. \& Ying, C. (2005). Cytogenetic analysis of nasal mucosa cells and lymphocytes from high-level long-term formaldehyde exposed workers and lowlevel short-term exposed waiters. Mutation Research, 588, $22-27$.

Yokel, R. \& MacPhail, R. (2011). Engineered nanomaterials: exposures, hazards, and risk prevention. Journal of Occupational Medicine and Toxicology. 21 -6:7.

Zhang, L., Steinmaus, C., Eastmond, D., Xianjun, K. \& Martyn, T. (2009). Formaldehyde exposure and leukemia: A new meta-analysis and potential mechanisms. Mutation Research, 681, 150-168. 


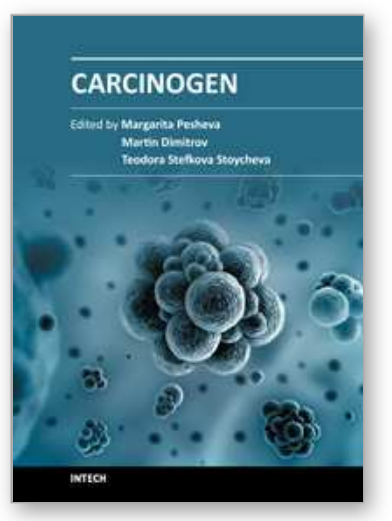

\author{
Carcinogen \\ Edited by Dr. Margarita Pesheva
}

ISBN 978-953-51-0658-6

Hard cover, 184 pages

Publisher InTech

Published online 13, June, 2012

Published in print edition June, 2012

During the last decades, cancer diseases have increased all over the world. The low quality of food and strong pollution of environment are the main prerequisites for carcinogenesis. The main problem for scientists is to find strategy for prevention of cancer diseases. Therefore, the information about the models for studying carcinogenesis and mutagens which appear during cooking, environmental pollutants, and tests for specific detection of carcinogens is particularly important. The book "Carcinogen" is intended for biologists, researchers, students in medical sciences and professionals interested in associated areas.

\title{
How to reference
}

In order to correctly reference this scholarly work, feel free to copy and paste the following:

Susana Viegas, Carina Ladeira, Mário Gomes, Carla Nunes, Miguel Brito and João Prista (2012). Genotoxic Effects of Exposure to Formaldehyde in Two Different Occupational Settings, Carcinogen, Dr. Margarita Pesheva (Ed.), ISBN: 978-953-51-0658-6, InTech, Available from:

http://www.intechopen.com/books/carcinogen/genotoxic-effects-of-occupational-exposure-to-formaldehyde

\section{INTECH}

open science / open minds

\section{InTech Europe}

University Campus STeP Ri

Slavka Krautzeka 83/A

51000 Rijeka, Croatia

Phone: +385 (51) 770447

Fax: +385 (51) 686166

www.intechopen.com

\section{InTech China}

Unit 405, Office Block, Hotel Equatorial Shanghai

No.65, Yan An Road (West), Shanghai, 200040, China 中国上海市延安西路65号上海国际贵都大饭店办公楼 405 单元

Phone: +86-21-62489820

Fax: +86-21-62489821 
(C) 2012 The Author(s). Licensee IntechOpen. This is an open access article distributed under the terms of the Creative Commons Attribution 3.0 License, which permits unrestricted use, distribution, and reproduction in any medium, provided the original work is properly cited. 